\title{
Conquering terra firma: The copper problem from the isopod's point of view
}

\author{
WOLFGANG WIESER \\ Institut für Zoologie der Universität Innsbruck, Innsbruck, Österreich
}

\begin{abstract}
KURZFASSUNG: Eroberung des Festlands: Das Kupferproblem vom Gesichtspunkt der Isopoden. Marine Crustaceen müßten theoretisch in der Lage sein, dem Atemwasser genügend viel Kupfer zu entnehmen, um selbst schwerste tägliche Verluste zu ersetzen. Im Vergleich dazu dürtte das in der Pflanzennahrung angebotene Cu mengenmäßig eine nur geringe Rolle spielen. Dennoch muß das vegetabilische $\mathrm{Cu}$ ausreichen, um den Bedarf herbivorer terrestrischer $\mathrm{Cru-}$ staceen an diesem Metall zu decken. Die Probleme, die im Zusammenhang mit der Immigration vom Meer zum Land hinsichtlich der Kupferversorgung entstehen, werden am Beispiel litoraler und terrestrischer Isopoden und Amphipoden - zum Teil in spekulativer Form - diskutiert. Vergleichende Untersuchungen haben ergeben, daß terrestrische und litorale Isopoden die Menge der aufgenommenen Nahrung gegenüber marinen Arten nicht erhöhen und daß die Assimilation von $\mathrm{Cu}$ aus der Nahrung in ausreichender Weise nur durch die Beihilfe von Mikroorganismen möglich zu sein scheint. Der Zugang zu einem nährstoffreichen, von Mikroorganismen gut durchgearbeitetem Substrat muß also eine der Hauptvoraussetzungen für eine funktionierende Kupferversorgung aus pflanzlichem Material sein. Außerdem nimmt die Menge des im Hepatopancreas gespeicherten $\mathrm{Cu}$ in der Reihe marine - litorale - terrestrische Crustaceen zu. Auch die Leistungsfähigkeit der Kupferassimilation ist im Vergleich zu litoralen bei terrestrischen Isopoden größer. Während bei Porcellio scaber die Kupferassimilation in direkter Abhängigkeit vom Kupfergehalt der Nahrung steht und Werte über $90 \%$ erreichen kann, beträgt bei Ligia oceanica und Orchestia gammarella die Kupferassimilation bei mittlerem Kupfergehalt $(0,2$ bis $0,3 \mu \mathrm{g} / \mathrm{mg}$ Trockengewicht) nur etwa $66 \%$, um dann wieder abzunehmen. Schließlich wird im Vergleich zu marinen und litoralen Isopoden der Kupferstoff wechsel terrestrischer Isopoden besser geregelt, indem $\mathrm{Cu}$ ausschließlicher in besonderen Zellen gespeichert und jede umfangreiche Mobilisierung des Metalls von der Synthese charakteristischer Sekrete begleitet wird, die Stoffe (wahrscheinlich Proteide) enthalten, deren Aufgabe zu sein scheint, freies $\mathrm{Cu}$ zu binden. Dies würde sowohl dessen toxische Eigenschaften reduzieren, als auch Verluste dieses Metalls an das Blut und in das Darmlumen verhindern.
\end{abstract}

\section{INTRODUCTION}

Amongst the numerous problems that faced marine animals when they attempted to extend their range of existence beyond the sea was that of how to replace the rich supply of nutrients given to their ancestors in the form of a medium which was not only a means of transport, but also an excellent solvent for inorganic and organic compounds. The conquerors of terrestrial habitats found themselves in the position of having to obtain now all body constituents (with the exception of oxygen and - 
occasionally - some water) from their food. This not only shifted the port of entry for a number of ions from gills and similar epithelia to the gut, it also caused additional complications in the case of those elements that abundantly occur in ionic form in sea water, but are present in the food largely as organic complexes. A case in point is copper; I shall try to outline some of the problems involved in the uptake and use of this element by referring to isopods (and amphipods) as if they "knew" what they were up against.

\section{RESULTS AND CONCLUSIONS}

Copper is an element of great biological importance since it is present in some vital enzyme systems as well as in the main respiratory pigment of crustaceans and molluscs. No thorough study has been made of the pathway of copper uptake in marine animals, but the work of ZuckerkandL (1960) and of Kerkut, Moritz \& Munday (1961) suggests that in crustaceans at least it is taken up from the medium via the gills. For cephalopods, however, as GHIRETTI \& VIOLANTE (1964) have shown, the main source of copper seems to be the food.

With respect to isopods the position for supplying the organism with a sufficient amount of copper is roughly the following: An isopod of $2 \mathrm{~cm}$ length, $0.5 \mathrm{~cm}$ width, weighing about $100 \mathrm{mg}$, has a gill area which measures at least $25 \mathrm{~mm}^{2}$. By creating turbulence currents a water layer $1 \mathrm{~mm}$ in thickness can be swept by the pleopods. Assuming a rate of water flow past the gills of $1 \mathrm{~cm} / \mathrm{sec}$, a volume of $200 \mathrm{ml} / \mathrm{hr}$ or approximately $5 \mathrm{l} /$ day will be filtered by the gills of the animal. This figure compares well with the rates of water transport in many ciliary feeders (BARKER-JøRGENSEN 1966).

Seawater contains from 5 to $20 \mu \mathrm{g}$ of copper per litre (HARvey 1955). In coastal areas where the transition from sea to land took place, the concentration may even be higher (recently, I measured 25 to $35 \mu \mathrm{g} / 1$ near the Zoological Station of Kristineberg, Sweden). Assuming a copper content of $20 \mu \mathrm{g} / 1$, an extraction coefficient of $25 \%$ and the rate of water flow indicated above, the model isopod should be able to extract from its medium 20 to $25 \mu \mathrm{g} \mathrm{Cu}$ /day. Since isopods of this size contain between 0.1 and $3 \mu \mathrm{g} \mathrm{Cu}$ in their main storing organ, the hepatopancreas (WIESER 1965a), it is clear that any loss of this metal - as, e. g., described by ZuckerkandL (1960) for moulting Maja squinado - could easily be compensated by uptake from the medium, provided a diffusion gradient is maintained between the latter and the body fluid.

In contrast, food would appear to offer only a fraction of the copper available in the medium. From the data presented for Naesa bidentata (WIEser 1962, 1963), it can be roughly estimated that herbivorous marine isopods consume a maximum of $100 \mu \mathrm{g}$ of dry algal food/mg of fresh body weight/day, which is equivalent to about $50 \mathrm{mg}$ of fresh algal food per animal and thus to a volume of $0.05 \mathrm{ml}$ of water, $10^{-5}$ times the volume of water passing the animal's gills in the same period of time. Species of Fucus concentrate copper from sea water by a factor of 100 to 600 (BLACK \& Mitchell 1952). Thus, even if extraction of this element from seaweeds could be engineered with the same efficiency as extraction from water, the food 
would supply only about 0.5 to $1 \%$ of the total copper available to the animals. There are, however, several reasons for suspecting that the extraction of copper from seaweeds is a much more costly process than uptake of this element from water. This is indicated by the fact that leaching in water hardly liberates any of the copper present in algae, the reason being that in plants copper forms organic complexes, mainly with proteins and carbohydrates (BLACK \& MrTCHELL 1952).

Now, crustaceans that have once migrated on land and thus do not benefit from the presence of copper dissolved in sea water will have to obtain this metal entirely through their food. Intertidal forms that are periodically covered by water could represent a transitional series with increasing dependence on food as the main source of this and other elements. Despite its relative unimportance as a copper source for herbivorous marine crustaceans, plant material per se still offers considerable amounts of this metal to clever consumers. If food contains $1 \%$ of the copper available to the animal in sea water, an isopod extracting it with $25 \%$ efficiency would obtain about $0.2 \mu \mathrm{g}$ per day, sufficient to compensate for a daily loss of onefifth of the copper stores of, say, Idotea neglecta. In order to exploit fully this potential source, terrestrial crustaceans could employ several stratagems; they could (1) increase food consumption, (2) improve the selective absorption of copper from the food material passing through the gut, (3) increase their copper stores, thus widening safety margins for times of need, (4) reduce copper losses by regulating the movements of this metal between the stores and other body compartments.

A quick evaluation of these pathways open to terrestrial and semi-terrestrial crustaceans shows that food consumption does not seem to increase with the acquisition of terrestrial habits. In the terrestrial isopod Porcellio scaber, specimens weighing $20 \mathrm{mg}$ consume a maximum of $100 \mu \mathrm{g}$ dry leaf litter per mg per day (WIESER 1965b), that is, an amount of dry organic material exactly equal to that calculated for representatives of the marine species Naesa bidentata of similar size. Moreover, an experimental feeding rate of $100 \mu \mathrm{g}$ dry organic matter $/ \mathrm{mg} / \mathrm{d}$ - for reasons given earlier (WIESER 1965b) - is almost certainly too high and under natural conditions might be reduced to $1 / 3$ in the case of $P$. scaber. An increase in food consumption therefore does not appear to be the isopod's method of choice for increasing its supply of copper.

The second possibility, improvement of selective extraction of copper from ingested food, turns out to be a tall order. As was shown before (WIESER 1966), terrestrial isopods seem to be incapable of assimilating copper from their natural diet, dead leaves, unless the latter have been artificially enriched to values far beyond those likely to occur in nature. It was postulated that an additional mechanism has to come into play in order to give terrestrial, herbivorous crustaceans access to copper, this mechanism being the participation of microorganisms. $P$. scaber, feeding on leaf litter, will at first loose copper through its faeces. Gradually the faeces accumulate and form a substrate for microbial activity in which organic complexes are broken down and copper is liberated. By reingesting their faeces, terrestrial isopods will now be able to assimilate the copper that was denied to them in the first place. In a limited sense, then, it can be said that micro-organisms replace seawater as the source of free copper in the ecological series from marine to terrestrial species of 
herbivorous crustaceans. The conclusion seems inevitable that one of the requirements of copper assimilation - and hence of survival - in terrestrial isopods must be access to a nutritive substrate rich in micro-organisms. This definitely sets the scene in which these immigrants were allowed to settle and to procreate on land.

Table 1

Copper budgets of specimens of L. oceanica and O. gammarella, based on feeding experiments with $F$ ucus vesiculosus in normal condition or artificially enriched with copper salts

\begin{tabular}{|c|c|c|c|c|c|}
\hline \multirow{2}{*}{ Species } & \multirow{2}{*}{ Sample no. } & \multicolumn{2}{|c|}{$\mu \mathrm{g} \mathrm{Cu} / \mathrm{mg}$ dry weight } & \multirow{2}{*}{$\frac{\text { Food } \mathrm{Cu}}{\text { Faeces } \mathrm{Cu}}$} & \multirow{2}{*}{$\begin{array}{l}\text { Food } \\
\text { artificially } \\
\text { enriched } \\
\text { with copper }\end{array}$} \\
\hline & & Food & Faeces & & \\
\hline \multirow{18}{*}{$\begin{array}{l}\text { Orchestia } \\
\text { gammarella }\end{array}$} & A 1 & 0.067 & 0.077 & 0.8 & - \\
\hline & A 2 & 0.07 & 0.1 & 0.7 & - \\
\hline & A 3 & 0.102 & 0,165 & 0.62 & - \\
\hline & A. 4 & 0.105 & 0.137 & 0.76 & - \\
\hline & A 5 & 0.125 & 0.065 & 1.95 & - \\
\hline & A 6 & 0.13 & 0.35 & 0.38 & - \\
\hline & A 7 & 0.15 & 0.07 & 2.15 & - \\
\hline & A 8 & 0.155 & 0.285 & 0.55 & + \\
\hline & A 9 & 0.17 & 0.39 & 0.45 & - \\
\hline & A 10 & 0.19 & 0.08 & 2.4 & - \\
\hline & A 11 & 0.19 & 0.225 & 0.85 & + \\
\hline & $\mathrm{A} 12$ & 0,23 & 0.25 & 0.93 & + \\
\hline & A 13 & 0.23 & 0.13 & 1.75 & - \\
\hline & A 14 & 0.25 & 0.3 & 0.86 & + \\
\hline & A 15 & 0.5 & 0.5 & 1.0 & + \\
\hline & A 16 & 0.96 & 0.72 & 1.35 & + \\
\hline & A 17 & 1.2 & 1.0 & 1.2 & + \\
\hline & A 18 & 1.4 & 1.1 & 1.27 & + \\
\hline \multirow{19}{*}{$\begin{array}{l}\text { Ligia } \\
\text { oceanica }\end{array}$} & B 1 & 0.078 & 0.27 & 0.29 & 一 \\
\hline & B 2 & 0.09 & 0.155 & 0.6 & - \\
\hline & B 3 & 0.104 & 0.27 & 0.4 & - \\
\hline & B 4 & 0.106 & 0.2 & 0.52 & - \\
\hline & B 5 & 0.12 & 0.2 & 0.63 & - \\
\hline & B 6 & 0.14 & 0.24 & 0.58 & - \\
\hline & B7 & 0.15 & 0.09 & 1.65 & - \\
\hline & B 8 & 0.18 & 0.15 & 1.2 & - \\
\hline & B 9 & 0.18 & 0.26 & 0.7 & + \\
\hline & B 10 & 0.185 & 0.35 & 0.53 & - \\
\hline & B 11 & 0.185 & 0.16 & 1.15 & - \\
\hline & B 12 & 0.195 & 0.07 & 2.8 & + \\
\hline & B 13 & 0.21 & 0.18 & 1.16 & - \\
\hline & B 14 & 0.23 & 0.38 & 0.6 & + \\
\hline & B 15 & 0.24 & 0.14 & 1.7 & - \\
\hline & B 16 & 0.28 & 0.117 & 2.4 & + \\
\hline & B 17 & 0.35 & 0.28 & 1.25 & - \\
\hline & B 18 & 0.38 & 0.19 & 2.0 & - \\
\hline & B 19 & 0.8 & 0.69 & 1.15 & + \\
\hline
\end{tabular}

Intertidal crustaceans are potentially able to choose between - or to combine the best - of two worlds. One might ask to what extent adaptations that have become a necessity for terrestrial species are already present in the intertidal forms. In order to pursue this question, an investigation into the copper budgets of Ligia oceanica and of 
the amphipod Orchestia gammarella was carried out in the summer of 1966 at the Zoological Station of Kristineberg in Sweden. The study was analogous to the one reported earlier with Porcellio scaber (WIESER 1966), Fucus vesiculosus from wrack beds - soaked in distilled water, sea water or in various solutions of copper sulfate and copper tartrate - serving as the food. The results are set out in Table 1 and in Figure 1, indicating that, as in P. scaber, assimilation of copper under experimental conditions

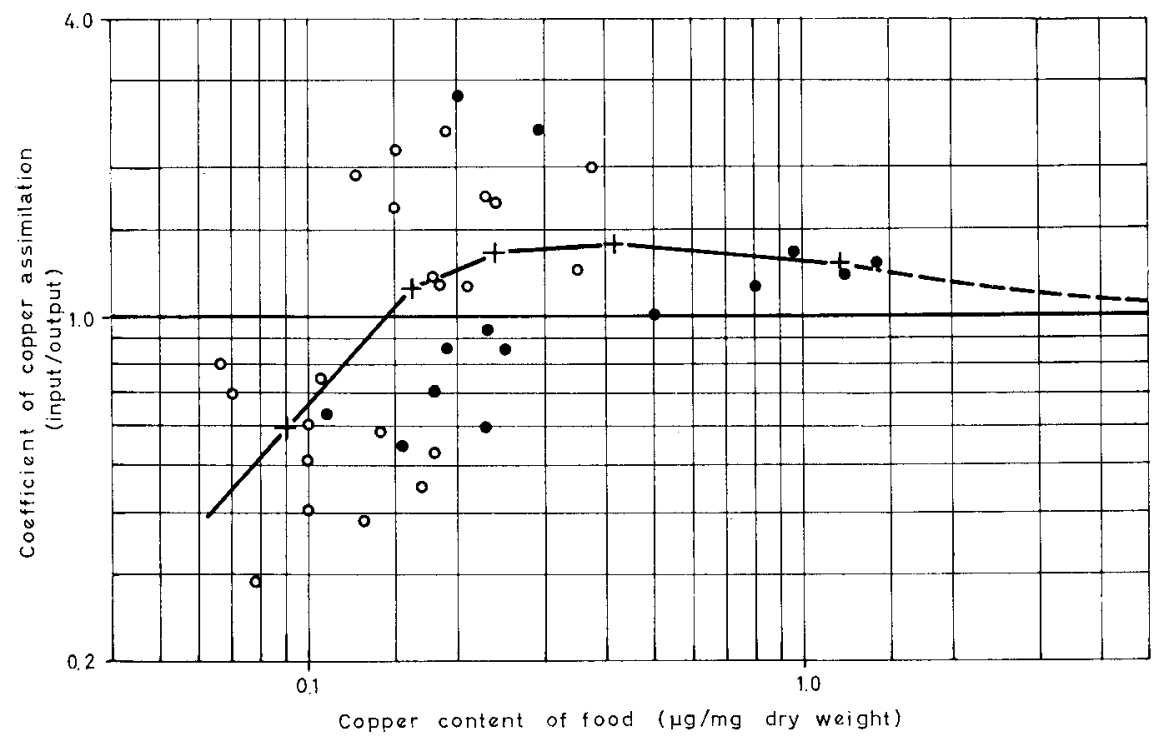

Fig. 1: Efficiency of assimilation (expressed by the ratio $\mathrm{Cu}$ input/Cu output) of $L$. oceanica and $O$. gammarella as a function of copper content of food (Fucus vesiculosus from wrack beds), the latter offered either in natural condition (empty circles) or after soaking in solution of copper sulfate or copper tartrate (full circles). The curve connects mean values of groups of points. For the copper determinations the organic material was ashed, dissolved in $3 \mathrm{ml}$ $1 \mathrm{~N}-\mathrm{HCl}$, shaken with $2 \mathrm{ml}$ of a $0.05 \%$ solution of zincdibenzyldithiocarbamate in $\mathrm{CCl}_{4}$, and the yellowish colour read at $435 \mathrm{~m} \mu$. Each symbol denotes one experiment. All experiments were performed in dishes with moist filter paper on the bottom at room temperature. Food was always in excess and each dish held many specimens of either of the two species

seems to be possible only when the metal is present at high concentrations. The "breaking even point" - i. e. the concentration at which copper is neither gained nor lost - is similar for the single species of amphipod and the two species of isopods, approximating 0.15 to $0.2 \mu \mathrm{g} \mathrm{Cu} / \mathrm{mg}$ dry food. However, in the case of the investigation carried out at Kristineberg, the copper content of $F$. vesiculosus from wrack beds turned out to be so high $(0.07$ to $0.38 \mu \mathrm{g} / \mathrm{mg} \mathrm{d}$. w.) that this seaweed could conceivably serve as the natural source of copper for the local populations of $L$. oceanica and $O$. gammarella. Its copper content is about one order of magnitude higher than the concentrations reported for $F$. vesiculosus from Plymouth by BLAck \& Mitchell (1952) but of approximately the same order as that given by the same authors for Laminaria digitata fronds. Contrary to the findings with $P$. scaber, enriching the food with copper salts did not increase the assimilation of copper in 
O. gammarella and L. oceanica (see below). At other localities where the water, and, consequently, the seaweeds, contain less copper than they do at Kristineberg, intertidal crustaceans would appear to be as much at a loss for obtaining their copper supplies through the primary vegetable material as $P$. scaber proved to be. Intertidal species have the advantage of being able to use the free $\mathrm{Cu}$ dissolved in sea water, and it will have to be the subject of further research to find out exactly to what extent they employ this possibility for dealing with their copper problems. If they do not, they

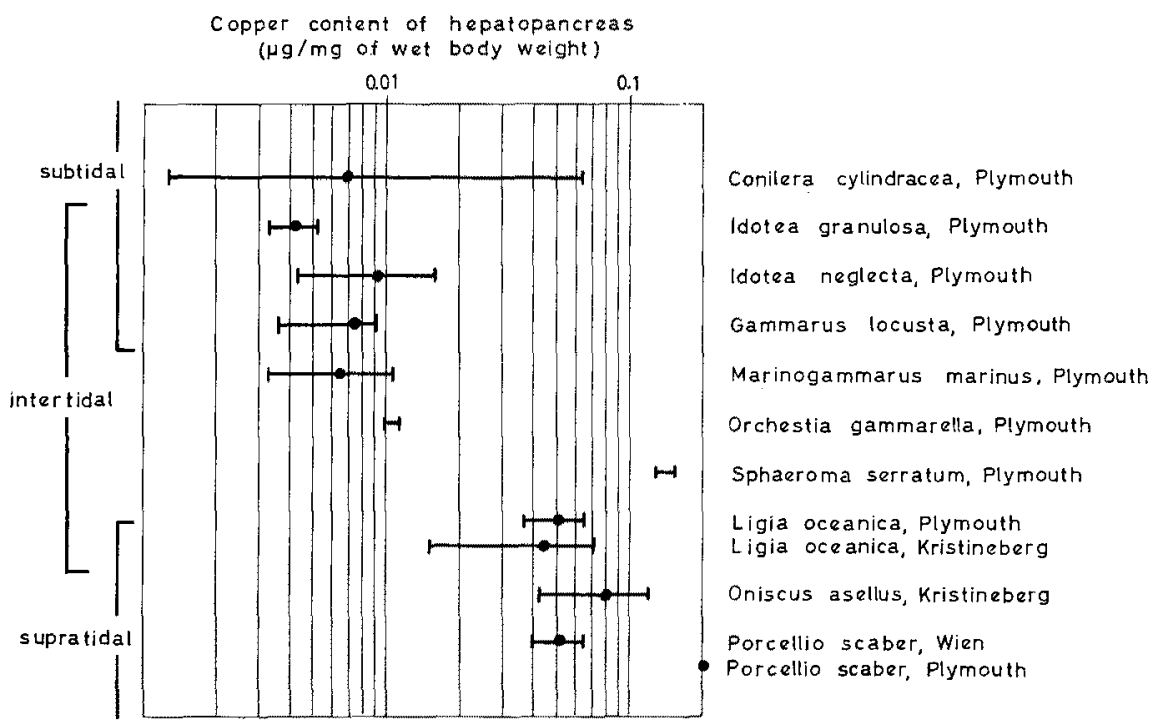

Fig. 2: Copper content of hepatopancreas (in $\mu \mathrm{g} \mathrm{Cu} / \mathrm{mg}$ fresh body weight) of several species of isopods and amphipods as a function of habitat. The vertical range of distribution of some of the species is indicated by the overlap of the three bars signifying the three main habitats distinguished

would either have to call for microbial assistance as their terrestrial cousins do, or they would have to prey on other crustaceans, exploiting the latter's ready made copper stores. O. gammarella has chosen the former solution since it lives in the wrack beds along the coast, an environment with a rich and varied microbial flora. In fact, O. gammarella is instrumental in bringing about the microbial degradation of the Fucus beds along the shore (REMMERT 1960) just as terrestrial isopods are instrumental in bringing about the microbial degradation of leaf litter on land. L. oceanica may also be found amongst dead seaweeds, but it is a truly omnivorous species and thus, theoretically at least, capable of covering its copper requirements by feeding on other crustaceans, just as Octopus vulgaris maintains its copper stores by preying on Carcinus maenas (GHIRETTI \& VIOLANTE 1964).

Marine isopods can always replenish their copper reserves from the ever present medium whereas intertidal and terrestrial species are not always exposed to optimum conditions for the replacement of lost copper. Consequently, it could be argued that increasing the copper stores in the body would be a feature of adaptive value in 
landbound immigrants from the sea. As has been pointed out before (WIESER 1965a), such an increase in hepatopancreas copper is in fact observed when isopods and amphipods are arranged in an ecological series from subtidal to supratidal and terrestrial species. The data, supplemented by new data for L. oceanica and Oniscus asellus from Sweden, are presented in Figure 2. An interesting case is that of Spbaeroma serratum, which usually is considered a truly marine species although its copper content places it amongst the terrestrial species. Now REMMERT (personal information) has discovered that at least some species of this genus indeed lead a nearly terrestrial existence.

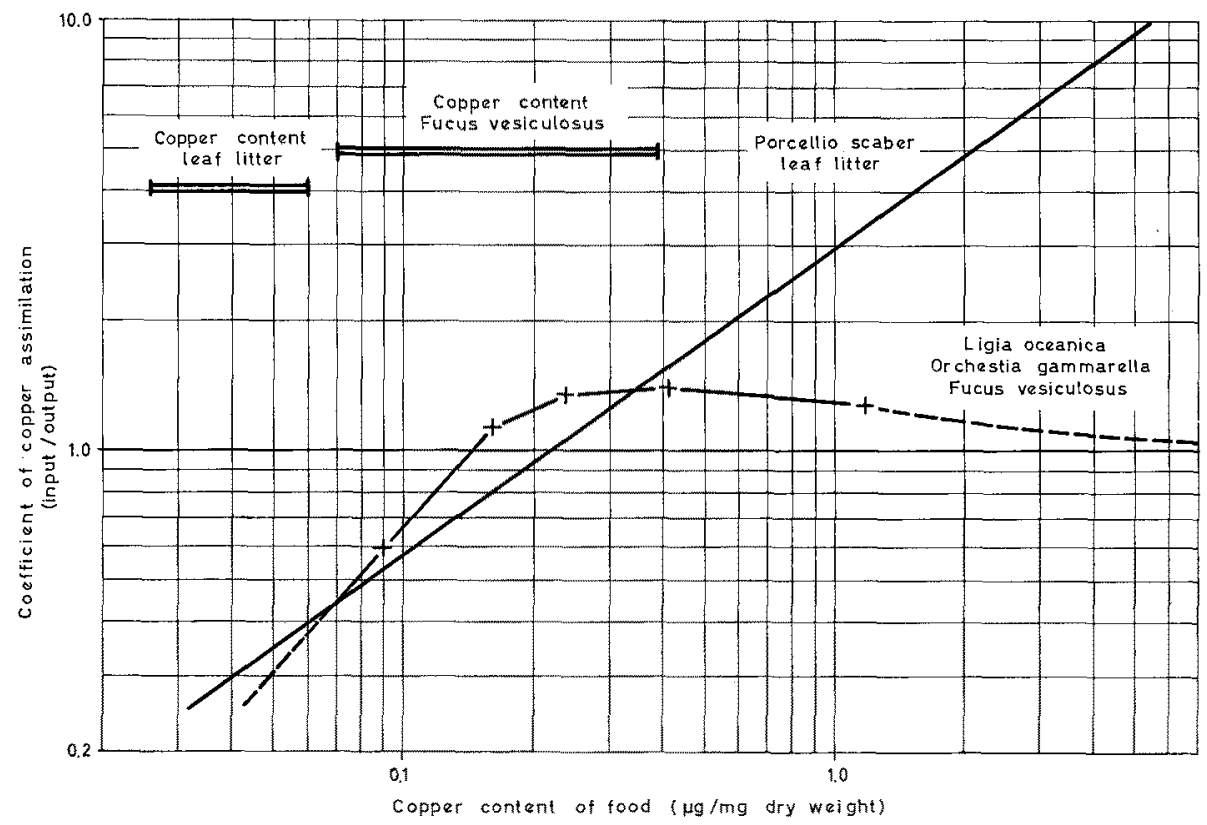

Fig. 3: Efficiency of assimilation as a function of copper content of food: comparison between Porcellio scaber feeding on leaf litter (straight regression line, taken from WIEsER 1966) after conversion of ash weights to dry weights and Ligia oceanica, Orchestia gammarella, feeding on Fucus vesiculosus (curve connecting crosses; mean values from Fig. 1). The natural range of copper content of the two kinds of food used is indicated by the two horizontal bars, top left of figure

Not only the storing capacity for copper increases in terrestrial isopods, but also their ability of assimilating this element from artificially enriched food. In $P$. scaber the assimilation of copper increases proportionally with the copper content of the food, reaching maximum values of more than $90 \%$ at food copper levels higher than $5 \mu \mathrm{g} / \mathrm{mg}$ dry weight (WIESER 1966). In L. oceanica and O. gammarella copper assimilation increases up to an input/output ratio of about 3 , equivalent to $66 \%$ assimilation, at food copper levels of 0.2 to $0.3 \mu \mathrm{g} / \mathrm{mg}$ dry weight. Increasing the copper content of food still more does not, however, increase the input/output ratio. On the contrary, in the few experiments in which members of these two species could 
be induced to feed on a high copper diet, the extraction efficiency dropped to values between zero and $30 \%$. It may therefore be concluded that the ability to extract and to store vast amounts of copper, if this element is presented in digestible form, is an adaptive characteristic of truly terrestrial species of isopods. Intertidal species may have high storing capacities too, but their ability (or, rather, their willingness?) to increase assimilation efficiency in direct proportion with the amount of copper offered in the diet is limited (Fig. 3). This must reflect their less precarious situation with respect to this food constituent.

Finally, there is the point of the regulation of copper content within the body. A marine crab like Maja squinado may lose $50 \%$ or more of its total copper during one moult (Zuckerkandr 1960). The copper content of the only subtidal species of isopod investigated so far, Conilera cylindracea, may vary over nearly two orders of magnitude (WIESER 1965a). This obviously is not an advantageous state of affairs if the acquisition of copper is as problematical as it turns out to be in terrestrial crustaceans. In consequence, the mode of copper storing and of copper mobilization seems to have changed in step with the conquest of land by isopods. In decapods copper may be stored in the form of pseudo-crystals or of large refractive bodies in special "copper cells" of the hepatopancreas (Ogura 1959); in isopods it can be found throughout the hepatopancreas in the form of small granules which represent the metal in an easily dissociable state that can be complexed with many chelating agents. As far as can be told, there are small cells in the hepatopancreas of these species in which copper is concentrated when it becomes plentiful. These "copper storing cells" grow more prominent as one goes from subtidal to intertidal to terrestrial species. In $L$. oceanica most of the copper occurs in small, conoid cells (the "Speicherzellen" or "S-Zellen" of FRENZEL 1894), but one can nearly always observe small amounts of "free" copper in the other cells of the hepatopancreas as well (Fig. 4a). The same holds for Sphaeroma serratum in which, however, the hepatopancreas has become so crowded with copper granules (Fig. 4b) that it is difficult to understand how this organ is capable of performing any function beyond the storage of copper. These distribution patterns are interpreted to indicate that in marine and intertidal species copper, though sometimes stored in specialized cells, is allowed to move rather freely from cell to cell. This again would suggest a high rate of loss via the hepatopancreatic lumen or the body fluids. In terrestrial isopods, however, copper is nearly always confined to the conoid S-cells which are squeezed in between the large, secretory B-cells (in FrenzeL's terminology; Fig. 4c). Whenever copper is being mobilized, for example during the moulting cycle (WIESER 1965c) or during periods of stress (unpublished observation), a special kind of protein-rich compound (also containing polysaccharids) is synthesized in the hepatopancreas cells, picking up the free copper and rendering it undetectable by histochemical means, i. e. changing the metal's state from "free" to tightly bound. At the end of such a cycle of activity the gluco-proteins break down, liberating the copper which for a short time may turn up in most of the cells of the hepatopancreas (Fig. $4 \mathrm{f}$ ).

However, soon all the copper will be concentrated again in the storing cells. This process of concentration is particularly striking during phases of holocrine secretion in which many of the large B-cells have disintegrated, leaving behind large stretches 

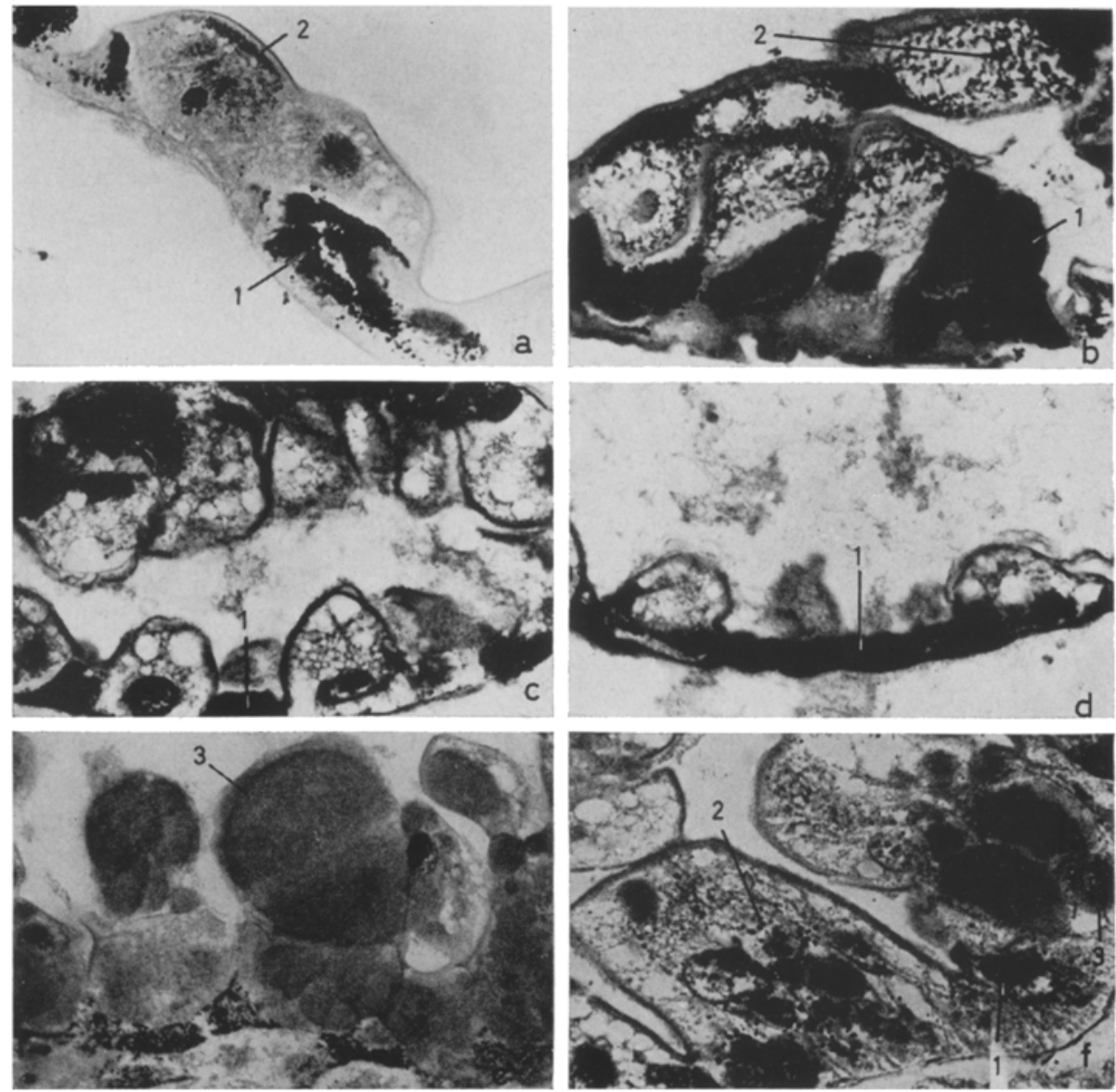

Fig. 4: Series of histological sections through hepatopancreas of isopods in order to show the distribution of copper. (a) Ligia oceanica and (b) Sphaeroma serratum, showing packed copper cells (1) and diffuse copper in B-cells (2); (c) Porcellio scaber, with large, copper-free B-cells and, between them, the smaller S-cells which in the three species represented here seem to be mainly copper storing cells; (d) $P$. scaber during moulting cycle, with copper-filled S-cells lining the hepatopancreas lumen and two spent B-cells. (e) $P$. scaber during moulting cycle, showing the protein-rich secretions (3) synthesized at certain steps of this process (WIESER $1965 \mathrm{c})$. At the stage shown here the copper granules are no longer confined to the storing cells and can be seen scattered throughout the hepatopancreas; gradually the copper "disappears" because it is picked up by organic material included in the secretions and in this state does not react with chelating agents any more. (f) $P$. scaber after a temperature stress. The same secretions have turned up in the hepatopancreas and the copper has become mobilized, occurring in a scattered way even in the large B-cells (2). The S-cells (1; pointing at nucleus) appear to be nearly free of copper. 1 : copper storing S-cells; 2 . diffuse copper in B-cells; 3 . secretory material, occurring during moulting cycle and in stress situations. All preparations fixed in absolute alcohol and stained with rubeanic acid in $\mathrm{Na}$-acetate buffer; counterstain with haemalum

of the hepatic tubule lined by small, cuboid cells, jampacked with copper (Fig. 4d). I have never observed free copper in the large B-cells unless accompained by the synthesis of special gluco-proteids, which at the peak of their development may fill 
most of these cells to the bursting point (Fig. 4e). The whole story behind the synthesis of this complex material in the isopod's hepatopancreas is far from clear, but there can be no doubt that it has some functional significance in connection with copper. Whatever else its role (e. g. in the synthesis of haemocyanin), by complexing the large stores of easily dissociable copper in the hepatopancreas, it protects the rest of the cells from this potentially toxic metal, as well as preventing the latter from being dissipated during the periods of synthesis and secretions which involve the whole organ. This recalls the remark of MANwELL \& BAKER (1963) that one of the important steps in the evolution of catalytic metalloproteids might have been the appearance of proteins which chelated free metal ions. The catalytic function of these proteids then developed as a sort of afterthought to their primary role as antitoxins.

Terrestrial isopods, by having manoeuvred themselves into a safety program of stockpiling copper far beyond what is called for by necessity, perhaps had to reinvent this old principle of chelation and transport of heavy metals by proteins in order to guide their stockpiles safely through the maze of metabolic processes going on in the same organ in which the metal has to be stored.

\section{SUMMARY}

1. Copper is an element of great importance for crustaceans such as isopods and amphipods. While their marine relatives can obtain all necessary chemical components from the surrounding sea water via gills or other epithelia, the species which have conquered terra firma face the problem of extracting practically all vital substances from their food.

2. In marine forms, the water flow maintained via ciliary or muscular mechanisms is sufficient to provide several orders of magnitude more copper than required; food probably plays only a minor role in copper supply.

3. Terrestrial isopods have to rely entirely on their food as a source of copper. They can do several things in order to ensure an adequate supply: increase food consumption, improve the selective absorption of copper from the food material passing through the gut (possibly in symbiosis with copper concentrating microorganisms), increase copper stores, thus widening safety margins for times of low supply, reduce copper losses by regulating the transport of this metal between the stores and other body parts.

4. It was shown that terrestrial isopods consume about as much food as their marine relatives.

5. Extraction of copper from primary vegetable matter seems to be very difficult, both for terrestrial forms like Porcellio scaber and for intertidal forms such as Ligia oceanica or the amphipod Orchestia gammarella; extraction is possible only at very high copper concentrations.

6. A way out of this calamitous situation seems to be in cooperation with microorganisms which liberate copper from the tightly bound states in which it exists in the primary plant material. This is true for $P$. scaber but it probably also holds for O. gammerella, L. oceanica and other species feeding on decaying algae on the shore. 
7. The amount of copper stored in the hepatopancreas increases with increasing dependence of the species on the terrestrial environment, the values obtained for intertidal species being intermediate between marine and truly terrestrial species.

8. P. scaber (and probably Oniscus asellus) will extract up to $95 \%$ of the copper present in artificially enriched leaf litter whereas intertidal forms feeding on Fucus will not extract more than $50 \%$, mostly only $20 \%$ or less, from artificially enriched seaweeds.

9. Copper is more strictly relegated to "storage cells" of the hepatopancreas in terrestrial isopods than it is in marine or intertidal ones. Extensive movements of copper in $P$. scaber are accompanied by the synthesis of special "carrier proteins", whereas in marine or intertidal species this metal seems to be able to move more freely in an easily dissociable state between the storage cells and other cells of the hepatopancreas.

\section{LITERATURE CITED}

Black, W. A. P. \& Mrtchell, R. L., 1952. Trace elements in the common brown algae and in sea water. J. mar. biol. Ass. U. K. 30, 575-584.

Frenzel, J., 1884: Über die Mitteldarmdrüse der Crustaceen. Mitt. zool. Stn Neapel 5, 50-101.

Ghirettr, F. \& Violante, U., 1964. Ricerche sul metabolismo del rame in Octopus vulgaris. Boll. Zool. 31, 1081-1092.

Harvey, H. W., 1955. The chemistry and fertility of sea waters. Univ. Pr., Cambridge, 224 pp.

Jørgensen, C. B., 1966. Biology of suspension feeding. Pergamon pr., Oxford, 357 pp.

Kerkut, G. A., Moritz, P. M. \& Munday, K. A., 1961. Variations of copper concentrations in Carcinus maenas. Cah. Biol. mar. 2, 399-408.

Manwell, C. \& BaKer, C. M., 1963. Starch gel electrophoresis of sera from some marine arthropods: studies on the heterogeneity of hemocyanin and on a "ceruloplasmin-like protein". Comp. Biochem. Physiol. 8, 193-208.

OguRA, K., 1959. Midgut gland cells accumulating iron or copper in the crayfish, Procambarus clarkii. Annotnes zool. jap. 32, 133-142.

Remmert, H., 1960. Der Strandanwurf als Lebensraum. Z. Morphol. Ökol. Tiere 48, 461-516.

WIESER, W., 1962. Adaptations of two intertidal isopods. 1. J. mar. biol. Ass. U.K. 42, 665-682.

- 1963. Adaptations of two intertidal isopods. 2. J. mar. biol. Ass. U. K. 43, 97-112.

- 1965a. Electrophoretic studies on blood proteins in an ecological series of isopod and amphipod species. J. mar. biol. Ass. U. K. 45, 507-523.

- 1965b. Untersuchungen über die Ernährung und den Gesamtstoff wechsel von Porcellio scaber (Crustacea: Isopoda). Pedobiol. 5, 304-331.

- 1965c. Über die Häutung von Porcellio scaber Latr. Zool. Anz. (Suppl. Bd) 28, 178-195.

- 1966. Copper and the role of isopods in degradation of organic matter. Science, N. Y. 153, 67-69.

Zuckerkande, E., 1960. Hémocyanine et cuivre chez un crustacé décapode, dans leurs rapports avec le cycle d'intermue. Annls Inst. océanogr., Monaco 38, 1-122.

\section{Discussion following the paper by WIESER}

Pandian: I would like to bring to your attention an unpublished work of a student from Madras University (India). He was interested in the estimation of ash content of the cuticle of crustaceans. Generally, the aquatic crustaceans have white ash, but surprisingly, that of 
Ligia sp. has blue. He concluded that copper contaminates the Ligia ash and that its cuticle serves as copper storage. Such studies seem to show that copper may be mobililized and moved to the cuticle, which then serves as an intermediary or permanent storage organ.

WIESER: This is an interesting observation and $\mathrm{I}$ would be grateful for a detailed reference to your colleague's work.

PAFFEnföfER: What kind of micro-organisms made the copper available for the crustaceans investigated?

WIEsER: I don't know.

HoHendorf: Für die funktionelle Abhängigkeit des Cu-Nutzkoeffizienten vom Kupferangebor in der Nahrung von Porcellio scaber zeigten Sie in einem doppelt-logarithmischen Koordinatensystem eine Gerade. In Wahrheit ist die Beziehung zwischen der Cu-Aufnahme und dem $\mathrm{Cu}$-Angebor jedoch keine lineare, sondern eine exponentielle. Durch Transformation in ein lineares System erhalten Sie für den funktionellen Zusammenhang eine Potenzfunktion, die in einem gewöhnlichen Koordinatensystem durch eine Parabel höheren Grades repräsentiert wird.

WIESER: $\mathrm{Da}$ die Beziehung zwischen Cu-Assimilation und Cu-Angebot im doppelt-logarithmischen Koordinatensystem als eine lineare erscheint, muß ihre Form im gewöhnlichen, linearen System natürlich einer Exponentialfunktion entsprechen. Ich habe keine Erklärung für diese Beziehung (die aussagt, daß mit steigendem Kupferangebot die Kupferassimilation exponentiell zunimmt), sondern nur die Vermutung, daß Kupfer in zwei Formen vorliegt: gebunden und frei. Mit steigendem Kupfergehalt nimmt der Anteil des freien Kupfers in der Nahrung außerordentlich schnell $z u$, da die Bindungsmöglichkeiten abgesättigt werden. Da freies Kupfer sehr viel leichter zu assimilieren ist als gebundenes, nimmt auch die Kupferassimilation in Abhängigkeit vom Zuwachs an freiem Kupfer sehr schnell zu. Wie gesagt, dies ist nur eine Vermutung. 